\title{
Mechanisms of synergism between cisplatin and gemcitabine in ovarian and non-small-cell lung cancer cell lines
}

\author{
CJA van Moorsel, HM Pinedo, G Veerman, AM Bergman, CM Kuiper, JB Vermorken*, WJF van der Vijgh \\ and GJ Peters
}

Department of Medical Oncology, University Hospital Vrije Universiteit, PO Box 7057, 1007 MB Amsterdam, The Netherlands

\begin{abstract}
Summary 2',2'-Difluorodeoxycytidine (gemcitabine, $\mathrm{dFdC}$ ) and cis-diammine-dichloroplatinum (cisplatin, CDDP) are active agents against ovarian cancer and non-small-cell lung cancer (NSCLC). CDDP acts by formation of platinum (Pt)-DNA adducts; dFdC by dFdCTP incorporation into DNA, subsequently leading to inhibition of exonuclease and DNA repair. Previously, synergism between both compounds was found in several human and murine cancer cell lines when cells were treated with these drugs in a constant ratio. In the present study we used different combinations of both drugs (one drug at its $\mathrm{IC}_{25}$ and the other in a concentration range) in the human ovarian cancer cell line A2780, its CDDP-resistant variant ADDP, its dFdC-resistant variant AG6000 and two NSCLC cell lines, H322 (human) and Lewis lung (LL) (murine). Cells were exposed for 4, 24 and $72 \mathrm{~h}$ with a total culture time of $96 \mathrm{~h}$, and possible synergism was evaluated by median drug effect

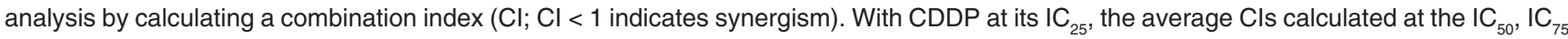
$\mathrm{IC}_{90}$ and $\mathrm{IC}_{95}$ after 4, 24 and $72 \mathrm{~h}$ of exposure were $<1$ for all cell lines, indicating synergism, except for the $\mathrm{Cl}$ after $4 \mathrm{~h}$ exposure in the LL cell line which showed an additive effect. With $\mathrm{dFdC}$ at its $\mathrm{IC}_{25}$, the Cls for the combination with CDDP after $24 \mathrm{~h}$ were $<1$ in all cell lines, except for the Cls after $4 \mathrm{~h}$ exposure in the LL and $\mathrm{H} 322$ cell lines which showed an additive effect. At $72 \mathrm{~h}$ exposure all Cls were $<1$. CDDP did not significantly affect dFdCTP accumulation in all cell lines. CDDP increased dFdC incorporation into both DNA and RNA of the A2780 cell lines 33- and 79-fold $(P<0.01)$ respectively, and tended to increase the dFdC incorporation into RNA in all cell lines. In the AG6000 and LL cell lines, CDDP and dFdC induced $>25 \%$ more DNA strand breaks (DSB) than each drug alone; however, in the other cell lines no effect, or even a decrease in DSB, was observed. dFdC increased the cellular Pt accumulation after $24 \mathrm{~h}$ incubation only in the ADDP cell line. However, $\mathrm{dFdC}$ did enhance the Pt-DNA adduct formation in the A2780, AG6000, ADDP and LL cell lines (1.6-, 1.4-, 2.9- and 1.6-fold respectively). This increase in Pt-DNA adduct formation seems to be related to the incorporation of dFdC into DNA $(r=0.91)$. No increase in DNA platination was found in the $\mathrm{H} 322$ cell line. $\mathrm{dFdC}$ only increased Pt-DNA adduct retention in the A2780 and LL cell lines, but decreased the Pt-DNA adduct retention in the AG6000 cell line. In conclusion, the synergism between dFdC and CDDP appears to be mainly due to an increase in Pt-DNA adduct formation possibly related to changes in DNA due to dFdC incorporation into DNA.
\end{abstract}

Keywords: cisplatin; gemcitabine; DNA damage; strand breaks; DNA adducts

cis-Diammine-dichloroplatinum (cisplatin, CDDP) is an established anticancer drug with activity in a variety of solid tumour types, including head and neck cancer (HNC), ovarian cancer and non-small-cell lung carcinoma (NSCLC). Its major disadvantage, however, is a relapse in most tumours after an initial response (Scanlon et al, 1991). CDDP is generally considered to exert its cytotoxic effect by binding to DNA, resulting in a number of different adducts (Sundquist et al, 1990). A tentative relationship between platinum-DNA adduct (Pt-DNA adduct) levels and antitumour response in cultured cells (Terheggen et al, 1990) and in patients has been postulated (Parker et al, 1991).

$2^{\prime}, 2^{\prime}$-Difluorodeoxycytidine (gemcitabine, $\mathrm{dFdC}$ ) is a deoxycytidine analogue (Hertel et al, 1988) with clinical activity against several solid tumours, such as ovarian cancer, NSCLC, HNC and pancreatic cancer (Van Moorsel et al, 1997). After entering the cell, $\mathrm{dFdC}$ is phosphorylated to its triphosphate (dFdCTP) which can be

Received 8 July 1998

Revised 4 November 1998

Accepted 4 December 1998

Correspondence to: GJ Peters incorporated into DNA, followed by one more deoxynucleotide, after which DNA polymerization stops (Huang et al, 1991), which probably determines its cytotoxic effect. Besides this effect, $\mathrm{dFdC}$ is also capable of inhibiting ribonucleotide reductase (RR) (Heinemann et al, 1988), an enzyme with a key role in DNA repair mechanisms.

Because of the mechanisms of action and different side-effects, CDDP being nephrotoxic and $\mathrm{dFdC}$ being myelotoxic, combination of these drugs has been investigated. In in vitro and in vivo studies a synergistic effect of both drugs was found in both CDDP-resistant and non-resistant tumours and tumour cell lines (Brakhuis et al, 1995; Bergman et al, 1996). Several possible mechanisms could be responsible for this interaction; CDDP might influence $\mathrm{dFdC}$ metabolism at its activation site or at the DNA level, while $\mathrm{dFdC}$ might interact with the accumulation of CDDP, the extent or nature of DNA platination, or the process of DNA repair. Previously, we observed that the accumulation of $\mathrm{dFdCTP}$ in a human ovarian cancer cell line (A2780) was not influenced by CDDP, but CDDP did cause a decrease of $40 \%$ of dFdCTP pools in the A2780 CDDPresistant variant, ADDP. DNA strand break (DSB) formation in A2780 cells was lower at simultaneous incubation of both drugs

*Present address: Department of Oncology, University Hospital Antwerp, Belgium. 
Table $1 \quad \mathrm{IC}_{50}$ s for all cell lines after 4-, 24- and 72-h exposure to each drug alone

\begin{tabular}{|c|c|c|c|c|c|c|}
\hline \multirow[t]{2}{*}{ Cell line } & \multicolumn{3}{|c|}{ CDDP $(\mu \mathrm{M})$} & \multicolumn{3}{|c|}{$\mathrm{dFdC}(\mathrm{nm})$} \\
\hline & $4 \mathrm{~h}$ & $24 \mathrm{~h}$ & $72 \mathrm{~h}$ & $4 \mathrm{~h}$ & $24 \mathrm{~h}$ & $72 \mathrm{~h}$ \\
\hline A2780 & $2.9 \pm 0.6$ & $1.2 \pm 0.5$ & $2.0 \pm 0.8$ & $12.4 \pm 2.7$ & $4.3 \pm 2.2$ & $2.2 \pm 1.0$ \\
\hline ADDP & $197 \pm 82$ & $63 \pm 15$ & $52 \pm 13$ & $239 \pm 117$ & $193 \pm 43$ & $625 \pm 154$ \\
\hline AG6000 & $17.1 \pm 4.5$ & $4.7 \pm 0.9$ & $4.5 \pm 1.0$ & $>10^{6}$ & $>10^{6}$ & $50500 \pm 20200$ \\
\hline H322 & $44.6 \pm 9.2$ & $15.3 \pm 3.7$ & $14.9 \pm 2.7$ & $708 \pm 335$ & $420 \pm 201$ & $120 \pm 54$ \\
\hline LL & $7.5 \pm 1.3$ & $2.7 \pm 0.7$ & $2.9 \pm 0.8$ & $800 \pm 100$ & $27.3 \pm 6.7$ & $12.8 \pm 4.4$ \\
\hline
\end{tabular}

The $\mathrm{IC}_{50}$ is defined as the concentration causing $50 \%$ growth inhibition in treated cells when compared to control cells. Values are means \pm s.e.m. of at least three separate experiments.

Table 2 Evaluation of the interaction between dFdC and CDDP in ovarian and NSCLC cell lines by median drug effect analysis

\begin{tabular}{|c|c|c|c|}
\hline \multirow[t]{2}{*}{ Cell line } & \multirow[t]{2}{*}{ Exposure time (h) } & \multirow{2}{*}{$\frac{\mathrm{dFdC} \text { at approximate } \mathrm{IC}_{25} \text { CDDP variable }}{\text { Average } \mathrm{Cl} \pm \mathrm{SEM}}$} & \multirow{2}{*}{$\frac{\mathrm{CDDP} \text { at approximate } \mathrm{IC}_{25} \mathrm{dFdC} \text { variable }}{\text { Average } \mathrm{Cl} \pm \mathrm{SEM}}$} \\
\hline & & & \\
\hline \multirow[t]{3}{*}{ A2780 } & 4 & $0.66 \pm 0.17$ & $0.45 \pm 0.09$ \\
\hline & 24 & $0.49 \pm 0.16$ & $0.40 \pm 0.06$ \\
\hline & 72 & $0.52 \pm 0.10$ & $0.41 \pm 0.09$ \\
\hline \multirow[t]{3}{*}{ ADDP } & 4 & $0.16 \pm 0.11$ & $0.19 \pm 0.05$ \\
\hline & 24 & $0.19 \pm 0.08$ & $0.40 \pm 0.02$ \\
\hline & 72 & $0.28 \pm 0.12$ & $0.29 \pm 0.08$ \\
\hline \multirow[t]{3}{*}{ H322 } & 4 & $0.58 \pm 0.31$ & $1.01 \pm 0.50$ \\
\hline & 24 & $0.59 \pm 0.08$ & $0.68 \pm 0.16$ \\
\hline & 72 & $0.43 \pm 0.16$ & $0.74 \pm 0.26$ \\
\hline \multirow[t]{3}{*}{ LL } & 4 & $1.31 \pm 0.32$ & $1.10 \pm 0.32$ \\
\hline & 24 & $0.46 \pm 0.20$ & $0.56 \pm 0.20$ \\
\hline & 72 & $0.43 \pm 0.16$ & $0.35 \pm 0.13$ \\
\hline
\end{tabular}

Values represent the average $\mathrm{Cls}$ (non-mutually exclusive) of the fractions affected (FA) of $0.5,0.75,0.90$ and 0.95 of the combination of $\mathrm{dFdC}$ and CDDP and are means of at least three separate experiments. Cells were exposed to the combination in a non-constant ratio, either with CDDP at its approximate IC ${ }_{25}$, or $\mathrm{dFdC}$ at its approximate $\mathrm{IC}_{25}$ combined with a range of the other drug with exposure times of 4-, 24- or 72-h exposure followed by 68-, 48- or 0-h drug-free period. $\mathrm{Cl}>1$ indicates antagonism, $\mathrm{Cl}=1$ is additive and $\mathrm{Cl}<1$ is synergism.

than with each compound alone (Bergman et al, 1996). It was therefore concluded that the synergistic interaction is possibly caused by an effect of $\mathrm{dFdC}$ on the cellular metabolism of CDDP. $\mathrm{dFdC}$ may inhibit DNA repair, leading to a decreased rate of repair of Pt-DNA adducts by the cancer cell.

The purpose of the present investigation was to elucidate possible mechanisms of synergism between $\mathrm{dFdC}$ and CDDP. Emphasis was on ovarian and NSCLC cells, since combinations of both compounds have led to increased response rates of up to $54 \%$ in NSCLC and $71 \%$ in ovarian cancer clinical studies (Steward et al, 1996; Abratt et al, 1997; Crino et al, 1997; Van Moorsel et al, 1997; Krakowski et al, 1998; Nogue et al, 1998).

We compared the effect of CDDP on accumulation of dFdCTP, $\mathrm{dFdC}$ incorporation into DNA and RNA, and the extent of DNADSB caused by the combination, with the effects of $\mathrm{dFdC}$ on the accumulation of CDDP and formation and retention of Pt-DNA adducts.

\section{MATERIALS AND METHODS}

\section{Drugs and chemicals}

$\mathrm{dFdC}\left(\right.$ Gemcitabine) and $\left[5-{ }^{3} \mathrm{H}\right]-\mathrm{dFdC}\left(16.7 \mathrm{Ci} \mathrm{mmol}^{-1}\right)$ were a kind gift of Eli Lilly Inc. (Indianapolis, IN, USA) and were solubilized with phosphate-buffered saline (PBS) to a concentration of $10 \mu \mathrm{M}$. CDDP (cisplatin) was obtained from Bristol-Myers Squibb (Woerden, The Netherlands) and solubilized with PBS to a concentration of $3 \mu \mathrm{M}$. Final dilutions of both drugs were made in culture medium. All other chemicals were of analytical grade and commercially available.

\section{Cell culture}

The experiments were performed with five different cell lines, with two major histological subtypes. For human ovarian cancer, A2780 was the parental cell line (Lu et al, 1988; Ruiz van Haperen et al, 1994a), ADDP, the variant with induced resistance to CDDP (Lu et al, 1988), and AG6000, the variant with induced resistance to gemcitabine (Ruiz van Haperen et al, 1994a). The ADDP cell line was included as a model for CDDP resistance due to both a decreased accumulation and Pt-DNA adduct formation. The AG6000 cell line was included as a negative control since gemcitabine is not activated in this cell line. For NSCLC we used the human $\mathrm{H} 322$ cell line (subtype BAC, NCI), and the murine LL tumour cell line (kindly provided by Dr Lelieveld). The murine cell line was included because this line is relatively resistant to CDDP and gemcitabine, both in-vitro and in-vivo. Therefore, the cell line was also used in simultaneously ongoing animal experiments 

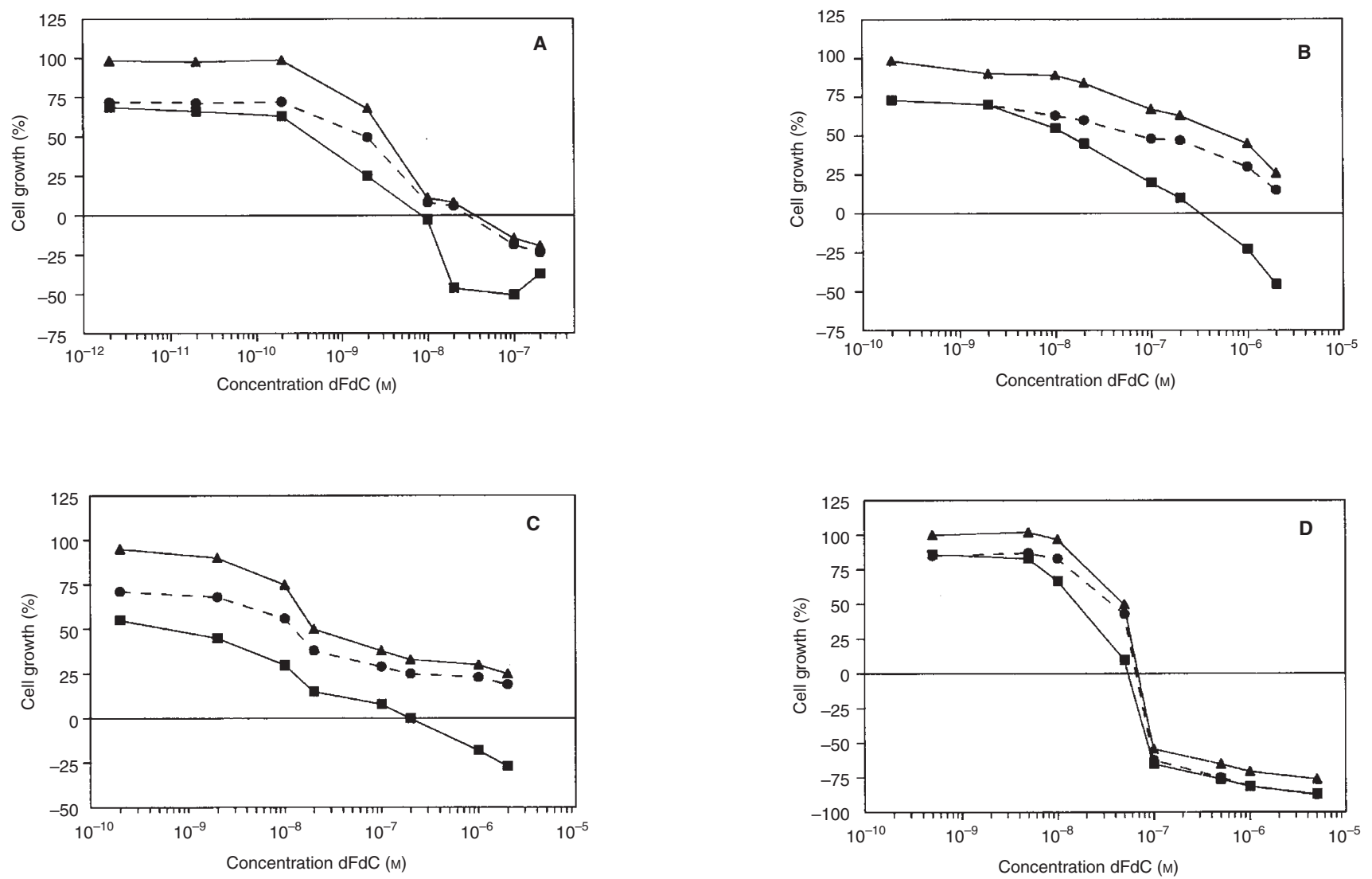

Figure 1 Representative growth inhibition curves of the cell lines A2780 (A), ADDP (B), H322 (C) and LL (D). Cells were exposed to dFdC alone (A) or in

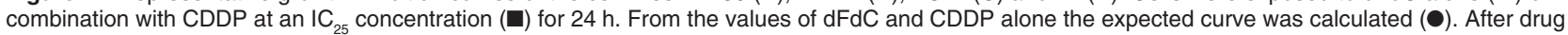
exposure, all cell lines were cultured in fresh medium. Total culture time was $72 \mathrm{~h}$. All growth inhibition assays were repeated at least three times and the variation between experiments was always lower than $34 \%$

(Van Moorsel et al, 1999). Doubling times of the cell lines were 21, $32,37,40$ and 26 h respectively. A2780 and AG6000 cells were cultured in Dulbecco's medium with 5\% heat-inactivated fetal calf serum (FCS). ADDP cells were cultured in RPMI medium with 5\% heat-inactivated FCS. H322 and LL cells were cultured in RPMI medium with $10 \%$ heat-inactivated FCS. A total of $250 \mathrm{ng} \mathrm{m}^{-1}$ gentamicin was added to the media. All cell lines were growing exponentially as monolayers during the course of all experiments.

\section{Growth inhibition experiments}

Growth inhibition experiments were performed in triplicate in 96well flat-bottom plates (Costar, Cambridge, MA, USA) essentially as described previously (Peters et al, 1993a). Cells were seeded in $100-\mu 1$ medium containing 5\% FCS at different densities; 6000 per well for A2780 cells, 12000 per well for ADDP cells, 20000 per well for H322 cells and 5000 per well for LL cells. After $24 \mathrm{~h}$, $100 \mu \mathrm{l}$ of drug containing medium was added and cells were cultured for another $72 \mathrm{~h}$. After 4 and $24 \mathrm{~h}$ the cells were washed and cultured in drug-free medium for 68 and $48 \mathrm{~h}$ respectively. Cells were exposed to $\mathrm{dFdC}$ alone or to CDDP alone, or to a combination of both drugs: one drug was added at a concentration causing about
$25 \%$ growth inhibition, while the other drug was added at variable concentrations. The used CDDP concentrations in A2780, ADDP, H322 and LL cells for 4-h exposure were 6, 320, 88 and $2.7 \mu \mathrm{M}$ respectively; for 24-h exposure 1.2, 160, 30 and $1.5 \mu \mathrm{M}$ respectively; and for $72-\mathrm{h}$ exposure $1.2,120,30$ and $1.5 \mu \mathrm{M}$ respectively. The used dFdC concentrations in A2780, ADDP, H322 and LL cells for 4-h exposure were 30, 320, 120 and $405 \mathrm{~nm}$ respectively; for 24-h exposure 4.8, 320, 40 and $10 \mathrm{nM}$ respectively; and for 72-h exposure $4.8,1400,20$ and $10 \mathrm{~nm}$ respectively. The CDDP concentration range for all cell lines was $10 \mathrm{nM}$ to $0.5 \mu \mathrm{M}$, the $\mathrm{dFdC}$ concentration range was $0.02 \mathrm{nM}$ to $1 \mu \mathrm{M}$ in A2780 cells, $0.2 \mathrm{nM}$ to $2 \mu \mathrm{M}$ in ADDP and $\mathrm{H} 322$ cells and $5 \mathrm{nM}$ to $10 \mu \mathrm{M}$ in LL cells. Growth inhibitory effects were evaluated with the standard sulphorhodamine B protein (SRB) assay (Peters et al, 1993a). Growth of the cells was exponential during the whole incubation period. Relative growth was calculated as described previously (Monks et al, 1991; Peters et al, 1993a) by: $\left[\left(\mathrm{OD}_{\text {treated }}-\mathrm{OD}_{\text {zero }}\right) /\left(\mathrm{OD}_{\text {control }}-\mathrm{OD}_{\text {zero }}\right)\right] \times 100 \%$, when $\mathrm{OD}_{\text {treated }}$ was $\geq$ to $\mathrm{OD}_{\text {zero }}$. In case $\mathrm{OD}_{\text {treated }}$ was below $\mathrm{OD}_{\text {zero }}$, cell killing had occurred. The optical density (OD) was read at $540 \mathrm{~nm}$. The $\mathrm{OD}_{\text {zero }}$ depicts the cell number at the moment of drug addition, the $\mathrm{OD}_{\text {control }}$ reflects the cell number of untreated wells and the $\mathrm{OD}_{\text {treated }}$ reflects the cell number in treated wells at the day of the assay. 
Table 3 Effect of CDDP on the relative incorporation of dFdC into DNA and RNA of ovarian and lung cancer cells, corrected for inhibition of DNA and RNA synthesis

\begin{tabular}{|c|c|c|c|c|c|c|c|c|}
\hline \multirow[b]{3}{*}{ Cell line } & \multirow{2}{*}{\multicolumn{4}{|c|}{ Ratio: $\frac{\mathrm{dFdC} \text { incorporation into DNA }}{\text { TdR incorporation into DNA }}$}} & \multirow{2}{*}{\multicolumn{4}{|c|}{ Ratio: $\frac{\mathrm{dFdC} \text { incorporation into RNA }}{\text { UR incorporation into RNA }}$}} \\
\hline & & & & & & & & \\
\hline & $\mathrm{dFdC}$ alone & & $\mathrm{dFdC}+\mathrm{CDDP}$ & & $\mathrm{dFdC}$ alone & & $\mathrm{dFdC}+\mathrm{CDDP}$ & \\
\hline A2780 & $0.02 \pm 0.01$ & $(95 \%)$ & $0.76 \pm 0.16^{a}$ & $(99 \%)$ & $0.10 \pm 0.02$ & $(0 \%)$ & $7.94 \pm 0.88^{\mathrm{a}}$ & $(87 \%)$ \\
\hline ADDP & $0.05 \pm 0.02$ & $(92 \%)$ & $0.03 \pm 0.01$ & $(80 \%)$ & $0.12 \pm 0.03$ & $(0 \%)$ & $0.64 \pm 0.04$ & $(0 \%)$ \\
\hline H322 & $0.30 \pm 0.03$ & (99\%) & $0.07 \pm 0.02$ & $(98 \%)$ & $0.85 \pm 0.09$ & $(0 \%)$ & $1.53 \pm 0.40$ & $(50 \%)$ \\
\hline LL & $0.00 \pm 0.00$ & (76\%) & $0.01 \pm 0.00$ & (71\%) & $0.38 \pm 0.07$ & $(0 \%)$ & $0.55 \pm 0.14$ & $(0 \%)$ \\
\hline
\end{tabular}

Cells were exposed to $0.1 \mu \mathrm{M} \mathrm{dFdC}$ alone, or in combination with $20 \mu \mathrm{m}$ CDDP, for $24 \mathrm{~h}$. Incorporation of ${ }^{3} \mathrm{H}-\mathrm{dFdC}$ into DNA and RNA was divided by the incorporation of TdR into DNA, and UR into RNA respectively. Values are means \pm s.e.m. of three separate experiments (\% DNA or RNA synthesis inhibition caused by the drug(s)). aSignificantly different from $\mathrm{dFdC}$ alone $(P<0.01)$.

Table 4 Effects of dFdC and CDDP on DNA strand break (DSB) formation in ovarian and lung cancer cells after 24-h exposure to both compounds alone or in combination

\begin{tabular}{|c|c|c|c|c|c|}
\hline \multirow[t]{2}{*}{ Cell line } & \multicolumn{2}{|c|}{ Concentration } & \multicolumn{3}{|c|}{$\%$ DSB } \\
\hline & $\mathrm{dFdC}(\mathrm{nm})$ & CDDP $(\mu \mathrm{M})$ & $\mathrm{dFdC}$ & CDDP & $\mathrm{dFdC}+\mathrm{CDDP}$ \\
\hline A2780 & 1.5 & 0.75 & $-2.4 \pm 5.8$ & $10.7 \pm 10.4$ & $-3.4 \pm 8.2$ \\
\hline ADDP & 1.5 & 0.75 & $38.9 \pm 9.2$ & $-4.2 \pm 21.2$ & $18.6 \pm 24.0$ \\
\hline AG6000 & 1.5 & 0.75 & $23.8 \pm 1.6$ & $-44.4 \pm 30.5$ & $6.8 \pm 33.9$ \\
\hline H322 & 100 & 5 & $22.3 \pm 5.4$ & $9.7 \pm 9.7$ & $-0.7 \pm 2.3$ \\
\hline LL & 10 & 2 & $-1.4 \pm 23.2$ & $-14.0 \pm 2.8$ & $18.5 \pm 2.9^{a}$ \\
\hline
\end{tabular}

Values (in \% decrease of amount of double-stranded DNA in untreated cells) are means \pm s.e.m. of three separate experiments. ${ }^{\text {a }} P=0.04$; measured DSB to expected DSB (DSB of both drugs added together). Expected DSB formation: 8.3\% in A2780, 34.7\% in ADDP, $-20.6 \%$ in AG6000, 32.0\% in $\mathrm{H} 322$ and $-15.4 \%$ in LL cells. For comparison data of Bergman et al (1996) on the A2780 cell line are included. Exposure of cells to $10 \mu \mathrm{m}$ VP-16 for $1 \mathrm{~h}$ was always included as an internal control for the assay and gave the following extent of DSB formation: A2780: $25.7 \pm 15.4$, ADDP: $20.9 \pm 10.8$, AG6000: 15.0 \pm 10.1 , H322: 19.3 \pm 7.4 and LL: $21.4 \pm 5.5 \%$. The actual levels of dsDNA in untreated cells at the end of the unwinding time were $86 \%$ in A2780, $96 \%$ in ADDP, $92 \%$ in AG6000, $87 \%$ in H322 and $49 \%$ in LL cells. These values were subsequently set at $100 \%$ to calculate the relative values.

We evaluated possible synergism using the median drug effect analysis method of Chou and Talalay $(1983,1994)$, processed by a computer program developed by Chou and Hayball (1996) and commercially available as CalcuSyn (Biosoft, Cambridge, UK). $\mathrm{D}_{\mathrm{m}}$ values $\left(\mathrm{IC}_{50}\right.$ values) are calculated by the program by extrapolation. For the separate drugs, the respective growth inhibition parameters, expressed as fraction affected (FA) (e.g. a FA of 0.25 is a growth inhibition of $25 \%$ ) were introduced. The CI (combination index) was calculated by the formula: $\mathrm{CI}=\left[(D)_{1} /\left(D_{x}\right)_{1}\right]+$ $\left[(D)_{2} /\left(D_{x}\right)_{2}\right]+\left[a(D)_{1}(D)_{2} /\left(D_{x}\right)_{1}\left(D_{x}\right)_{2}\right]$. Where $a=1$ for mutually non-exclusive drugs; $(D)_{1}$ and $(D)_{2}$ are the doses of the separate drugs and their combination; and $\left(D_{x}\right)_{1}$ and $\left(D_{x}\right)_{2}$ are the doses resulting in a growth inhibition of $\mathrm{x} \%$. These doses are calculated by the formula: $D=D_{m}[F A /(1-F A)]^{1 / m}$, where $D_{m}$ is the dose required to produce a $50 \%$ growth inhibition, $F A$ is the fraction affected, and $m$ is the slope of the median plot. Since CIs changed with FA, the averaged CIs at $\mathrm{IC}_{50}, \mathrm{IC}_{75}, \mathrm{IC}_{90}$ and $\mathrm{IC}_{95}$ were used. An average $\mathrm{CI}<1$ indicates synergism, $>1$ indicates antagonism and an average $\mathrm{CI}$ of 1 indicates additivity.

\section{dFdCTP accumulation}

The effect of CDDP on the accumulation of dFdCTP was studied by exposing $2-4 \times 10^{5}$ cells, in 6 -well plates in duplicate, to $\mathrm{dFdC}$ $(0.1 \mu \mathrm{M}, 1 \mu \mathrm{M})$, or to $\mathrm{dFdC}$ and CDDP $(20 \mu \mathrm{M}, 200 \mu \mathrm{M})$ for $24 \mathrm{~h}$. As a control, non-exposed cells were cultured for the same period.
At the end of the incubation cells were washed in ice-cold PBS, harvested by rapid trypsinization ( $1 \mathrm{~min}$ at room temperature) and subsequently suspended in ice-cold culture medium with FCS, immediately followed by chilling on ice and cell counting. Nucleotides were extracted and analysed by HPLC as described previously (Bergman et al, 1996; Ruiz van Haperen et al, 1994b). Separation and quantification of the normal ribonucleotides and of dFdCTP was achieved with a gradient HPLC system (Partisphere SAX anion exchange column) connected to a photo-diode array detector, regularly set at 254 and $280 \mathrm{~nm}$ as described previously (Ruiz van Haperen et al, 1994b). Peaks were quantitated by a data acquisition program.

\section{[5- $\left.{ }^{3} \mathrm{H}\right]-\mathrm{dFdC}$ incorporation}

Incorporation of ${ }^{3} \mathrm{H}-\mathrm{dFdC}$ into DNA and RNA was performed essentially as described previously for measuring the incorporation of 5-fluorouracil (5-FU) into RNA and DNA and ${ }^{3} \mathrm{H}$-deoxyuridine into DNA (Peters et al, 1987; Van der Wilt et al, 1993) using 96well filter-bottom plates (Multiscreen ${ }^{\circledR}$ Filtration System, $0.22 \mu \mathrm{m}$ Hydrophilic Low Protein Binding Durapore ${ }^{\circledR}$ Membrane, Millipore, Molsheim, France). Briefly, cells (about 150000 per well in $100 \mu \mathrm{l}$ culturing medium) were plated and, after $24 \mathrm{~h}$ of recovery, incubated with $\left[5-{ }^{3} \mathrm{H}\right]-\mathrm{dFdC}\left(22 \mathrm{Ci} \mathrm{mmol}^{-1}\right)(0.1$ and $0.4 \mu \mathrm{M})$ alone, or in combination with CDDP $(20$ and $200 \mu \mathrm{M})$ for $24 \mathrm{~h}$ at $37^{\circ} \mathrm{C}$. The incubation was terminated by the addition of 


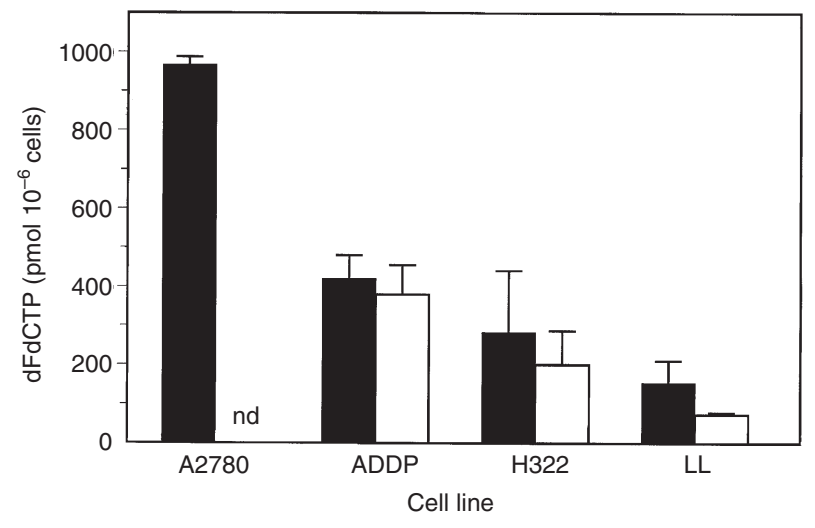

Figure 2 Effect of CDDP on the accumulation of dFdCTP. For comparison, previously published effects of the A2780 cell line are also included (Bergman et al, 1996). Cells were exposed for $24 \mathrm{~h}$ to either $1 \mu \mathrm{m} \mathrm{dFdC}$ alone (black bars) or in combination with $200 \mu \mathrm{M}$ CDDP (white bars). Values are means \pm s.e.m. of three to five experiments. ND = not detectable, in A2780 because of cell death after combination of both compounds at these concentrations. AG6000 did not accumulate dFdCTP (Ruiz van Haperen et al, 1994)

trichloroaretic acid (TCA) as described previously by Van der Wilt et al (1993). Incorporation into RNA was determined by adding 40 $\mu 1$ DNAase I $\left(1 \mathrm{mg} \mathrm{ml}^{-1}\right)$ and $60 \mu \mathrm{l}$ PBS to one part of the wells and an incubation for $30 \mathrm{~min}$ at $37^{\circ} \mathrm{C}$. Incorporation into DNA was determined by adding $20 \mu \mathrm{l}$ RNAase A/T1 (500 $\mathrm{U} \mathrm{ml}^{-1}$; DNAasefree) and $80 \mu \mathrm{l}$ PBS to the other part of the wells and incubation for $30 \mathrm{~min}$ at $37^{\circ} \mathrm{C}$. The reaction was terminated by precipitation of RNA and DNA, respectively, with TCA. Filters were washed with water and ethanol and, subsequently, the filters were incubated with $\mathrm{NaOH}$ to hydrolyse nucleic acids and counted. To determine the amount of cells, duplicate cultures were exposed to similar concentrations of non-radiolabelled $\mathrm{dFdC}$, harvested by rapid trypsinization and counted. ${ }^{3} \mathrm{H}-\mathrm{dFdC}$ incorporation into DNA and RNA was corrected for inhibition of DNA and RNA synthesis, as measured by the incorporation of $\left[2-{ }^{14} \mathrm{C}\right]$-thymidine $\left({ }^{14} \mathrm{C}-\mathrm{TdR}, 62.8 \mathrm{Ci} \mathrm{mol}^{-1}\right.$, $2.5 \mu \mathrm{M})$ and $\left[5-{ }^{3} \mathrm{H}\right]$-uridine ( $\left.{ }^{3} \mathrm{H}-\mathrm{UR}, 27 \mathrm{Ci} \mathrm{mmol}^{-1}, 58.6 \mathrm{~nm}\right)$ added to control cells and cells exposed for $24 \mathrm{~h}$ to $\mathrm{dFdC}$ and CDDP, respectively, $2 \mathrm{~h}$ before the end of the incubation, using a similar protocol as described before (Ruiz van Haperen et al, 1993). A ratio was calculated between $\mathrm{dFdC}$ incorporation into DNA and RNA, and TdR and UR incorporation into DNA and RNA, respectively, as follows:

DNA: (fmol dFdC in DNA $10^{-6}$ cells)/(fmol TdR in DNA $10^{-6}$ cells) RNA: (fmol dFdC in RNA $10^{-6}$ cells)/(fmol UR in RNA $10^{-6}$ cells)

\section{FADU DNA-damage assay}

The extent of DNA strand breaks (DSB) caused by $\mathrm{dFdC}$ and $\mathrm{dFdC}$ in combination with CDDP were measured by the FADU assay (Fluorometric Analysis of DNA Unwinding) as described previously by Birnboim and Jevcak (1981) and slightly modified (Bergman et al, 1996; Van der Wilt, 1997). This assay is based on the principle that the rate of unwinding of DNA under alkaline conditions depends on the presence of strand breaks; DNA with a high amount of strand breaks will unwind faster under alkaline conditions than DNA with no strand breaks. Double-stranded DNA (dsDNA) can be detected by ethidium bromide (EtBr) staining. Cells (about $5 \times 10^{6}$ cells) were incubated with CDDP

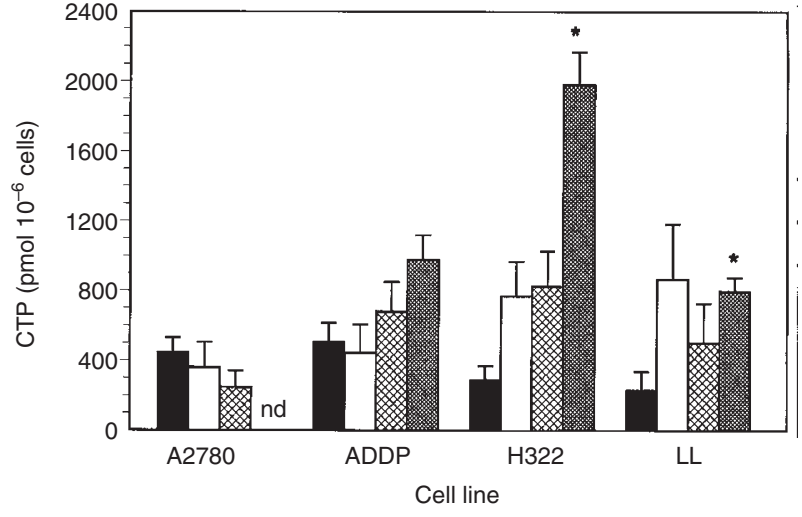

Figure 3 CTP pools in the A2780, ADDP, H322 and LL cell lines in control cells (black bars), or after exposure of cells to $1 \mu \mathrm{m} \mathrm{dFdC}$ alone (white bars), $200 \mu \mathrm{M}$ CDDP alone (crossed bars), or in combination (dense crossed bars) for $24 \mathrm{~h}$. Values are means \pm s.e.m. of three to five experiments. ND = not detectable, in A2780 because of cell death after combining both compounds at these concentrations. ${ }^{*}$ Significantly different from control levels, $P<0.05$

alone (ADDP and AG6000: $750 \mathrm{nM}$; H322: $5 \mu \mathrm{M}$; LL: $2.5 \mu \mathrm{M}$ ) or in combination with $\mathrm{dFdC}$ (ADDP and AG6000: $1.5 \mathrm{nM}$; H322: $100 \mathrm{nM}$; LL: $10 \mathrm{nM}$ ) for $24 \mathrm{~h}$ at $37^{\circ} \mathrm{C}$. Etoposide (VP-16) was used as a positive control drug, and added at $50 \mu \mathrm{M}$ to the cells $1 \mathrm{~h}$ before harvesting. Untreated cells were used as controls. Cells were harvested, kept on ice and directly used in the assay. For this purpose the cells were suspended in $2 \mathrm{ml}$ ice-cold $0.25 \mathrm{M}$ mesoinositol, $10 \mathrm{~mm} \mathrm{NaH} \mathrm{PO}_{4}, 1 \mathrm{~mm}$ magnesium chloride (pH 7.2) and the suspension was divided equally among three sets of tubes: T-, B- and P-tubes. All tubes were incubated with a buffer containing a high concentration of urea to disrupt the chromatin. T-tubes (total fluorescence) were then treated with glucose containing buffer, to stabilize DNA so that unwinding could not occur due to the alkaline environment. Subsequently, alkaline buffer was added. B-tubes (background fluorescence) were vortexed vigorously so that the dsDNA is sheared. All tubes were incubated at $15^{\circ} \mathrm{C}$ so that the DNA could unwind and were then put on ice. The glucose-containing buffer was then added to the Ptubes (estimate of unwinding rate of the DNA caused by the drug) and B-tubes. EtBr was added to all tubes and all tubes were vortexed. The fluorescence was measured and the extent of DNA strand breaks was calculated by: $(\mathrm{P}-\mathrm{B}) /(\mathrm{T}-\mathrm{B}) \times 100 \%$.

\section{Total cellular platinum accumulation}

Cells (about $5 \times 10^{6}$ cells) were incubated with CDDP alone (20 and $200 \mu \mathrm{M})$, or in combination with $\mathrm{dFdC}(0.1$ and $1 \mu \mathrm{M})$ for $24 \mathrm{~h}$ at $37^{\circ} \mathrm{C}$. Cells were trypsinized, washed three times with ice-cold PBS, harvested, counted and stored as pellets at $-20^{\circ} \mathrm{C}$. Before analysis, $500 \mu \mathrm{l}$ benzethonium hydroxide (hyamine) per $1 \times 10^{6}$ cells was added to the cell pellets. A total of $25 \mu \mathrm{l}$ water was added to the samples and standard curves were made by addition of $25 \mu \mathrm{l}$ of standard CDDP-solutions $(0.1-0.3 \mu \mathrm{M})$ in water to $1 \times 10^{6}$ non-treated cells; all samples were vortexed and incubated overnight at $55^{\circ} \mathrm{C}$; thereafter $4.25 \mathrm{ml} 0.2 \mathrm{M}$ hydrochloric acid was added. Samples were analysed on a Varian SpectrAA-10 atomic absorption spectrometer (Varian UK, Walton-on-Thames, Surrey, UK) equipped with a graphite furnace; data were formatted and archived on a personal computer utilizing Varian Report Manager software. Samples were dried at $95-110^{\circ} \mathrm{C}$, ashing was performed at $1300^{\circ} \mathrm{C}$ and atomization at $2600^{\circ} \mathrm{C}$. 


\section{Platinum-DNA adduct determination}

Cells were treated with CDDP $(20$ and $200 \mu \mathrm{M})$ alone or in combination with $\mathrm{dFdC}(0.1$ and $1 \mu \mathrm{M})$ for $24 \mathrm{~h}$ at $37^{\circ} \mathrm{C}$. After this time period drugs were washed away and cells were cultured in drugfree medium for another 3, 6 or $24 \mathrm{~h}$. Cells were washed with PBS, trypsinized and harvested on ice; the cell pellets (about $5 \times 10^{6}$ cells) were resuspended in $1.0 \mathrm{ml}$ lysis-buffer (100 mM Tris, $5 \mathrm{~mm}$ EDTA, 0.2\% sodium dodecyl sulphate, $200 \mathrm{~mm}$ sodium chloride, $100 \mathrm{mg} \mathrm{ml}^{-1}$ proteinase $\mathrm{K}, \mathrm{pH} 8.5$ ) and incubated for 2 days at $37^{\circ} \mathrm{C}$ with agitation. DNA was precipitated by mixing with 2-propanol and dissolved in TE-buffer (10 mM Tris, $1 \mathrm{~mm}$ EDTA, pH 7.5). DNA content was estimated by measuring optical density at 260 and $280 \mathrm{~nm}$ (protein content), all samples had an $\mathrm{OD}_{260} / \mathrm{OD}_{280}$ ratio $>1.9$ indicating uncontaminated DNA. A total of 0.1 volume sodium chloride $(1.65 \mathrm{M})$ was added to the dissolved DNA. A calibration curve was made using different solutions of CDDP $(0-1.5$ $\mu \mathrm{M})$ in TE-buffer containing $0.165 \mathrm{M}$ sodium chloride. Pt content of samples and standards was measured using AAS.

\section{Statistical evaluation}

Results were evaluated using the paired and unpaired Student's $t$-test. Relations between parameters were evaluated using the Pearson's correlation test.

\section{RESULTS}

\section{Analysis of the interaction between $\mathrm{dFdC}$ and CDDP}

The $\mathrm{IC}_{50} \mathrm{~s}$ of $\mathrm{dFdC}$ and CDDP alone in the A2780, ADDP, AG6000, H322 and LL cell lines are summarized in Table 1. Clear differences were observed in the sensitivity for both drugs in these cell lines: at all exposure times A2780 is the most sensitive cell line for both compounds, followed by LL. The ADDP, AG6000 and $\mathrm{H} 322$ cell lines all are very resistant to $\mathrm{dFdC}(>50$-fold compared to A2780). ADDP is the most resistant cell line to
CDDP ( $>45$-fold resistant), followed by H322 (> 7.5-fold resistant) and AG6000 (>3.5-fold resistant). Based on these sensitivity data, combination experiments were designed in which cells were exposed to the approximate $\mathrm{IC}_{25}$ of one drug and a concentration range of the other drug. From the separate growth inhibition data, expected curves could be calculated. Figure 1 shows representative growth inhibition curves for $\mathrm{dFdC}$ alone, the combination of $\mathrm{dFdC}$ and CDDP, and the expected growth inhibition curves in the A2780, ADDP, H322 and LL cell lines. It was remarkable that in the A2780, ADDP and H322 cell lines the highest difference between the expected and measured curve was observed at the $\mathrm{IC}_{100}$ concentration of $\mathrm{dFdC}$.

Synergism was analysed with the median drug effect analysis of Chou and Talalay $(1983,1994)$, average CIs of the FA 0.5, 0.75, 0.90 and 0.95 are given in Table 2. At 4-h exposure of cells to the approximate $\mathrm{IC}_{25}$ of $\mathrm{dFdC}$ in combination with CDDP synergism was found in the A2780, ADDP and H322 cell lines. However, slight antagonism was found in the LL cell line. At 24- and 72-h exposures synergism was found in all cell lines. At 4-h exposure to $\mathrm{CDDP}$ at the approximate $\mathrm{IC}_{25}$ and to $\mathrm{dFdC}$ in a concentration range, the combination was synergistic in the two ovarian cancer cell lines A2780 and ADDP. However, additivity was found in the H322 cell line and moderate antagonism in the LL cell line. At 24and 72-h exposures synergism was found in all cell lines.

\section{Effects on dFdCTP accumulation and normal nucleotide pools}

In order to determine a possible role of $\mathrm{dFdCTP}$ in the interaction between $\mathrm{dFdC}$ and CDDP, we measured the accumulation of $\mathrm{dFdCTP}$ after 24-h exposure to $1 \mu \mathrm{M} \mathrm{dFdC}$ alone, or in combination with $200 \mu \mathrm{M}$ CDDP in the A2780, ADDP, H322 and LL cell lines (Figure 2). dFdCTP accumulation after exposure to $1 \mu \mathrm{M}$ $\mathrm{dFdC}$ alone for $24 \mathrm{~h}$ did not show a clear relation with the sensitivity of this panel of cell lines. A2780 cells, which are the most sensitive to $\mathrm{dFdC}$, clearly accumulated the highest amount of

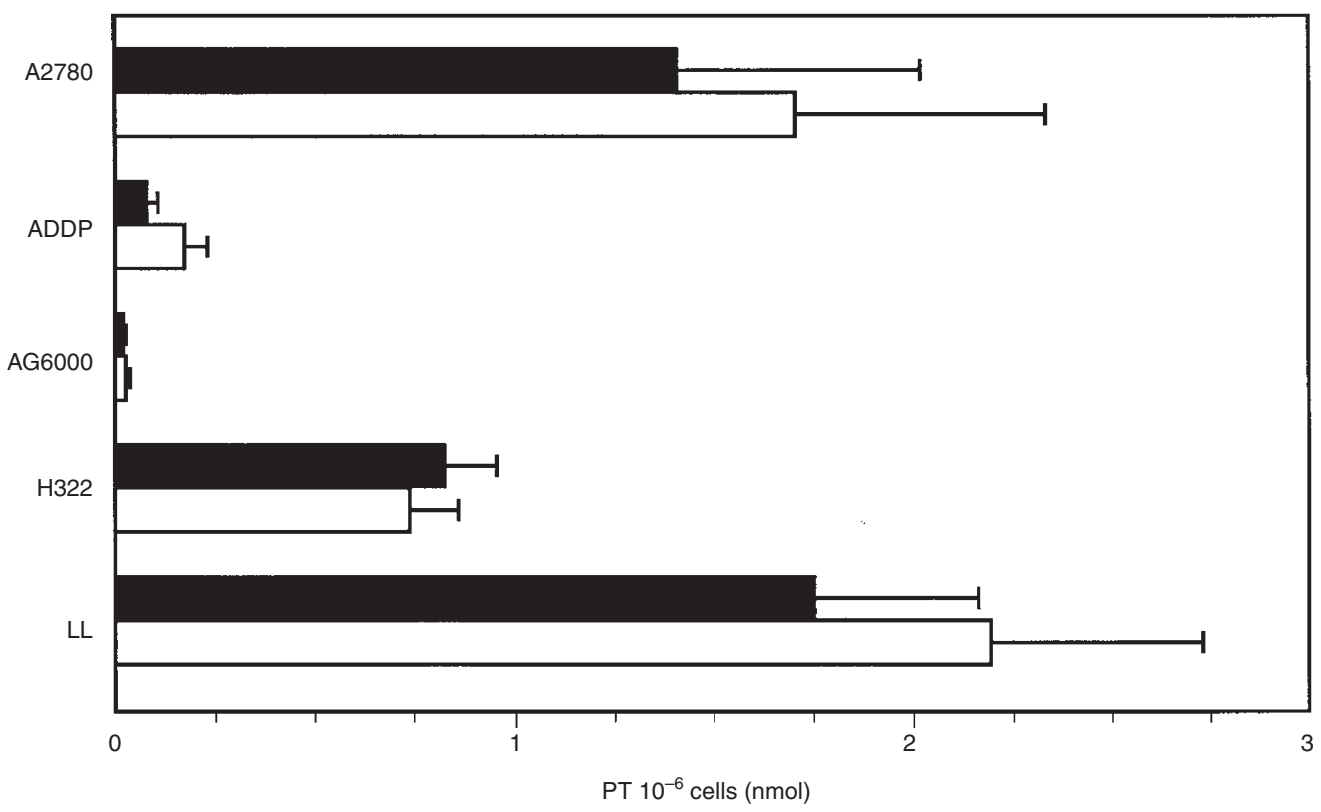

Figure 4 Effect of dFdC on the cellular accumulation of platinum in ovarian and lung cancer cell lines. Cells were exposed to either CDDP alone $(200 \mu \mathrm{M})(\square)$ or in combination with dFdC $(1 \mu \mathrm{M})(\square)$ for $24 \mathrm{~h}$. Values are means \pm s.e.m. of three to four experiments 

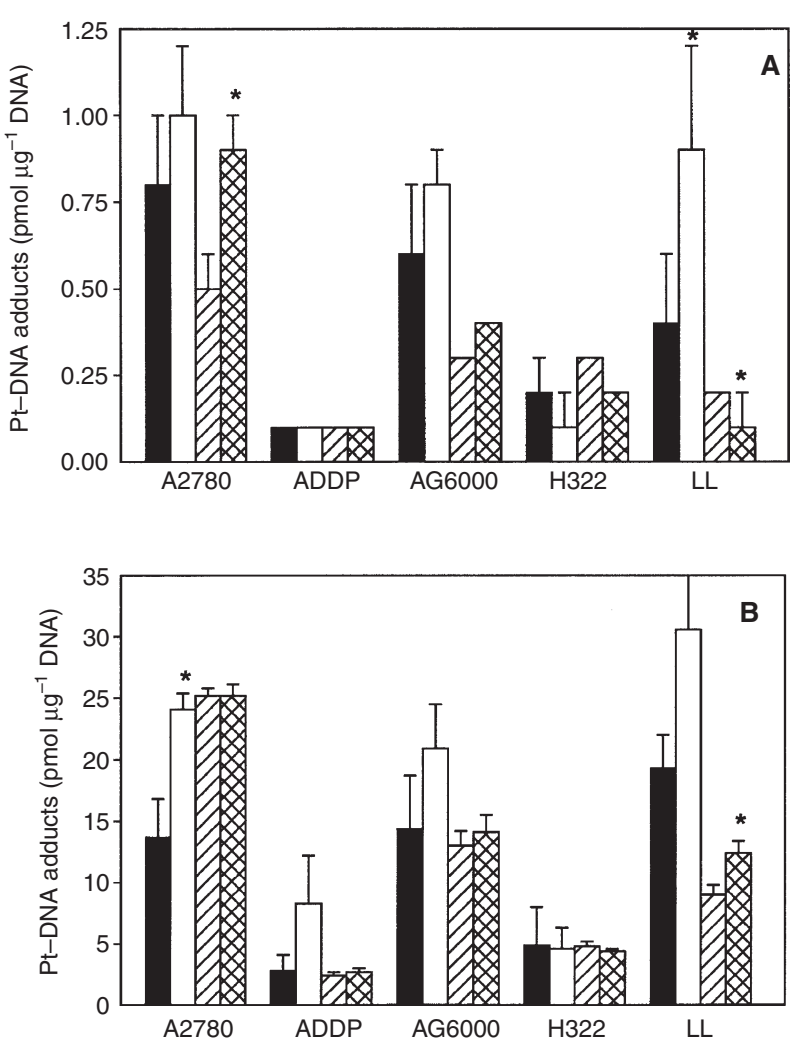

Figure 5 Pt-DNA adduct levels in DNA after 24-h exposure to CDDP alone (solid bars) or CDDP and dFdC in combination (open bars), and 3-h incubation in drug-free medium (hatched bars: CDDP alone; double hatched bars: CDDP and dFdC in combination. (A) Results of $20 \mu \mathrm{m}$ CDDP and $0.1 \mu \mathrm{m} \mathrm{dFdC}$. (B) Results of $200 \mu \mathrm{m}$ CDDP and $1 \mu \mathrm{m} \mathrm{dFdC}$. This Figure shows the mean data of at least three experiments \pm s.e.m. *Significantly different from CDDP alone, $P<0.05$

dFdCTP. However, LL cells, which are the second most sensitive to $\mathrm{dFdC}$, accumulate the lowest amount of dFdCTP. CDDP did not cause any significant changes in $\mathrm{dFdCTP}$ accumulation, even though it tended to decrease $\mathrm{dFdCTP}$ accumulation 10, 25 and $50 \%$ in the ADDP, H322 and LL cell lines respectively. In A2780 cells, the combination of both compounds at these concentrations was too toxic for reliable measurements of the dFdCTP accumulation. Normal nucleotide pools were evaluated in the same analysis; only CTP pools showed relevant changes and are shown in Figure 3. Incubation with $1 \mu \mathrm{M} \mathrm{dFdC}$ alone tended to increase CTP pools 2.6- and 3.7-fold in the H322 and LL cell lines $(P=0.09$ and $P=0.13$ ) respectively, whereas no differences were found in the A2780 and ADDP cell lines. CDDP alone also tended to increase CTP pools in the H322 line 2.8-fold $(P=0.07)$. However, the combination of both compounds resulted in a significant increase of CTP pools in the ADDP, H322 and LL cells (1.9-, 6.7- and 3.4fold; $P=0.06, P<0.01$ and $P=0.03$ respectively).

\section{dFdC incorporation into DNA and RNA}

To determine the possible contribution of $\mathrm{dFdC}$ incorporation into DNA and RNA to the interaction between both compounds, incorporation of $\left[5-{ }^{3} \mathrm{H}\right]-\mathrm{dFdC}$ into DNA and RNA was studied. Within the panel of human cell lines the most sensitive cell line to $\mathrm{dFdC}$, A2780, incorporated threefold more $\mathrm{dFdC}$ into DNA $(P=0.02$ and $P=0.01$ respectively) and fivefold more $\mathrm{dFdC}$ into RNA than the

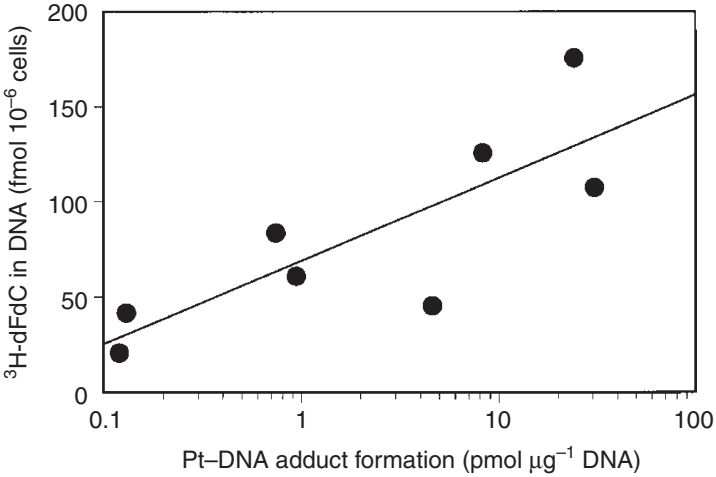

Figure 6 Correlation between ${ }^{3} \mathrm{H}-\mathrm{dFdC}$ incorporation into DNA (data not shown) and initial Pt-DNA adduct formation (Figure 5) in the A2780, ADDP, H322 and LL cell lines. Pearson correlation $r=0.91$. $P$-value (two-tailed) $=0.02$

more resistant cell lines ADDP and H322 respectively $(P<0.01$ for both cell lines) (results not shown). However, the A2780 cell line incorporated threefold less $\mathrm{dFdC}$ into DNA than the lesssensitive murine LL cell line $(P=0.02)$. The amount of $\mathrm{dFdC}$ incorporation into DNA did not show a clear relation with the dFdCTP accumulation in these cell lines. The LL cell line accumulated the lowest amount of dFdCTP; however, it incorporated the highest amounts of dFdC into both DNA and RNA. Together this possibly resulted in the rather sensitive phenotype.

The effects of CDDP on $\mathrm{dFdC}$ incorporation into DNA and RNA were corrected for the incorporation of TdR and UR into DNA and RNA as a parameter for DNA and RNA synthesis (Table 3). Using this correction, CDDP increased $\mathrm{dFdC}$ incorporation into both DNA and RNA of the A2780 cell line 33- and 79-fold $(P<0.01)$ respectively, and did not influence the incorporation of $\mathrm{dFdC}$ into DNA in the other cell lines. CDDP tended to increase the $\mathrm{dFdC}$ incorporation into RNA in all cell lines. For the high drug concentrations (both $\mathrm{dFdC}$ and CDDP), DNA and RNA synthesis were completely inhibited and no reliable ratio could be calculated.

\section{DSB formation}

The extent of DSB formation after exposure to either CDDP or $\mathrm{dFdC}$ alone, or to a combination of both compounds, was measured to determine the possible contribution of this type of DNA damage to the interaction between both compounds (Table 4). Expected values were calculated by addition of the amount of DSB formed by each compound alone. In the wild-type ovarian cancer cell line A2780, in the CDDP-resistant ADDP cells and in the NSCLC H322 cells less DSB than expected tended to be formed by the combination of $\mathrm{dFdC}$ and CDDP (differences: $11.7 \%, 16.1 \%$ and $32.7 \%$ respectively). However, in the dFdCresistant AG6000 cells, and in the murine LL cells, more DSB than expected were formed $(27.4 \%$ and $33.9 \%$ respectively; not significant in AG6000 cells; $P=0.04$ in LL cells).

\section{Total cellular platinum accumulation}

The amount of total Pt accumulating in cells after exposure of cells to $\mathrm{CDDP}$ alone, or in combination with $\mathrm{dFdC}$, was determined to study whether $\mathrm{dFdC}$ would affect total cellular Pt accumulation. Figure 4 shows the $\mathrm{Pt}$ accumulation in the ovarian cancer and NSCLC cell lines after $24 \mathrm{~h}$ of incubation with either CDDP alone, 
or in combination with $\mathrm{dFdC}$. In the $\mathrm{A} 2780$ cell line, exposure to $200 \mu \mathrm{M}$ CDDP resulted in 60- and 17-fold higher Pt accumulation than in the CDDP-resistant variants AG6000 and ADDP respectively $(P<0.05)$. The NSCLC cell lines, H322 and LL, both accumulated more $P t$ than the resistant ovarian cancer cell lines. Total $\mathrm{Pt}$ accumulation in this panel apparently is not related to CDDP sensitivity. A significant effect of $\mathrm{dFdC}$ on $\mathrm{Pt}$ accumulation was only found in the ADDP cell line; $\mathrm{dFdC}$ caused a 2.1-fold increase of $\mathrm{Pt}$ accumulation in this cell line $(P=0.04)$.

\section{Pt-DNA adduct formation}

Formation of Pt-DNA adducts is a critical event in the cytotoxicity of CDDP. Therefore, we studied whether $\mathrm{dFdC}$ might affect the formation of Pt-DNA adducts and the Pt-DNA adduct retention (Figure 5A,B). The CDDP-resistant cell line ADDP clearly formed 4.9-fold fewer Pt-DNA adducts compared to its sensitive parental cell line A2780 $(P=0.02)$, which may be related to its lower total cell Pt accumulation. This was in contrast to the Pt-DNA adduct formation in the AG6000 cell line, which was similar to that in the A2780 cell line, although Pt accumulation in the AG6000 cells was much lower than in A2780 cells. The Pt-DNA adduct formation in the LL lung cancer cell line was fourfold higher than that in the H322 cells $(P<0.01)$, which was in line with the higher Pt accumulation in these cells. $\mathrm{dFdC}$ increased the Pt-DNA adduct formation compared to CDDP alone in all cell lines except in H322 and ADDP cells at the low concentrations. However, in the ADDP cell line, adduct levels were at the detection limit of the atomic absorption spectroscopy. At the high CDDP concentration, $\mathrm{dFdC}$ increased the Pt-DNA adduct formation in ADDP cells almost to the level found in A2780 cells treated with CDDP alone. The level of Pt-DNA adduct formation correlated with the incorporation of $\mathrm{dFdC}$ into DNA after $24 \mathrm{~h}$ exposure to $\mathrm{dFdC}$ alone (Figure 6).

The retention of the Pt-DNA adducts formed after exposure to $200 \mu \mathrm{M}$ CDDP was increased similarly at 3 (Figure 5B), 6 and $24 \mathrm{~h}$ (data not shown) by co-exposure to $1 \mu \mathrm{M} \mathrm{dFdC} \mathrm{in} \mathrm{the} \mathrm{LL} \mathrm{cell}$ line (1.4-, 1.3- and 1.3-fold; $P<0.01, P<0.18$ and $P<0.19$ respectively). However, in the $\mathrm{dFdC}$-resistant AG6000 cell line, the 6and 24-h Pt-DNA adduct levels in cells after treatment with the combination of $\mathrm{dFdC}$ and CDDP were $85 \%$ of the levels in cells treated with CDDP alone ( $P=0.10$ and $P<0.01$ respectively) (data not shown). In all other cell lines no effect of dFdC on the 3-, 6- and 24-h retention of Pt-DNA was found. However, in most cell lines the level of Pt-DNA adducts $24 \mathrm{~h}$ after exposure to CDDP did not decrease significantly compared to the 3-and 6-h levels. Only in the AG6000 cells did Pt-DNA adduct levels decrease to about 50\% of the initial levels (data not shown). It is possible that cells lacked an intact enzyme system due to these high concentrations, and thus were inhibited in their ability to repair DNA damage.

Therefore, we focused on the combination of $20 \mu \mathrm{M}$ CDDP and $0.1 \mu \mathrm{M} \mathrm{dFdC} \mathrm{(Figure} \mathrm{5A).} \mathrm{dFdC} \mathrm{significantly} \mathrm{increased} \mathrm{the} \mathrm{reten-}$ tion of Pt-DNA adducts in the A2780 cell line $(P<0.05)$. However, this effect did not last longer than $3 \mathrm{~h}$ and seemed to be due to the initial increase in Pt-DNA adduct levels rather than to DNA repair inhibition. In the LL cell line, $\mathrm{dFdC}$ caused a twofold decrease in Pt-DNA adducts after exposure to the low concentration of CDDP $(P=0.02)$. However, note that the Pt-DNA adduct levels after exposure to $20 \mu \mathrm{M}$ CDDP were just above the detection level. In the AG6000, ADDP and H322 cell lines, dFdC did not seem to affect $\mathrm{Pt}-\mathrm{DNA}$ adduct retention 3, 6 and $24 \mathrm{~h}$ after exposure.
When evaluated as total exposure to Pt-DNA adducts, in all cell lines except for the H322, the areas under the curve for Pt-DNA adduct levels tended to be higher for the $\mathrm{dFdC}-\mathrm{CDDP}$ combination (a 1.5-, 2.2-, 1.4- and 1.8-fold increase in the A2780, ADDP, AG6000 and LL cell lines respectively (data not shown).

\section{DIscussion}

In this study we showed synergism between $\mathrm{dFdC}$ and CDDP in several ovarian cancer and NSCLC cell lines. The most pronounced effects were found in the CDDP-resistant cell lines when $\mathrm{CDDP}$ was used around its $\mathrm{IC}_{25}$ and $\mathrm{dFdC}$ in a concentration range. The mechanism of this synergistic interaction is most likely due to an increased Pt-DNA adduct formation, possibly related to the incorporation of $\mathrm{dFdC}$ into DNA.

Using a different approach of drug exposure than in previous studies, synergism was found in a panel of five different cell lines. It was remarkable that in some cell lines the best effect was observed at the $\mathrm{IC}_{100}$ concentration of $\mathrm{dFdC}$, indicating that the combination can exert significant anti-tumour activity by killing cells. The concentrations used in this study to achieve synergism are in agreement with levels of both drugs that can be reached in patients (Vermorken et al, 1984; Abbruzzese et al, 1991; Peters et al, 1993a; Freeman et al, 1995; Van der Uijgh, 1991). Combination of both compounds has led to increased response rates in various cancer types, such as ovarian cancer and NSCLC, in which response rates up to $71 \%$ were observed (Steward et al, 1996; Abratt et al, 1997; Crino et al, 1997; Van Moorsel et al, 1997; Krakowski et al, 1998; Nogue et al, 1998).

The present studies were performed to elucidate the mechanism of the interaction between $\mathrm{dFdC}$ and CDDP; therefore, various parameters related to the mechanism of action of both compounds were investigated. dFdCTP accumulation was related to sensitivity to $\mathrm{dFdC}$ of all cell lines tested in this study and in previous studies (Ruiz van Haperen et al, 1994b; Bergman et al, 1996) (except for the murine LL cells). CDDP did not cause any significant changes in $\mathrm{dFdCTP}$ accumulation, but tended to decrease the dFdCTP accumulation in the ADDP, H322 and LL cell lines. This phenomenon might be the result of the highly toxic combination of both compounds. However, since this decrease in $\mathrm{dFdCTP}$ accumulation was seen in $\mathrm{dFdC}$ - and CDDP-sensitive, as well as -resistant, cell lines in this study and in a previous study (Bergman et al, 1996), a more likely possibility is the rise in CTP and UTP pools, caused by both CDDP and $\mathrm{dFdC}$. Both CTP and UTP can moderately inhibit the activity of dCK in competition with ATP (Ruiz van Haperen et al, 1996), therefore a rise in CTP and UTP might decrease the accumulation of dFdCTP. However, CDDP might also inhibit dFdC uptake of cells directly, which was already shown for 2'-deoxy-5-azacytidine (DAC), another deoxycytidine analogue (Ellerhorst et al, 1993).

In this study, no relation was found between $\mathrm{dFdC}$ incorporation into DNA and sensitivity to $\mathrm{dFdC}$. The higher $\mathrm{dFdC}$ incorporation into DNA in LL cells than in the more dFdC-sensitive A2780 cell line might be due to the higher inhibition of DNA synthesis in A2780 cells, since this difference disappears after correction of the incorporation of $\mathrm{dFdC}$ for the inhibition of DNA synthesis. In the A2780 cell line, CDDP increased the incorporation of $\mathrm{dFdC}$ into DNA, possibly due to the inhibition of RR by both CDDP and dFdC (Heinemann et al, 1988; Chiu et al, 1992). Further research is warranted to study the mechanism responsible for the increase in $\mathrm{dFdC}$ incorporation into RNA and DNA by CDDP.

To study the possible interaction of both compounds with respect to DNA damage, we determined the effect of both drugs on 
DNA integrity. The only cell lines in which $\mathrm{dFdC}$ did not cause any damage were the ovarian cancer cell line A2780 and the murine cell line LL, whereas CDDP caused DNA damage only in A2780 and H322 cells. CDDP even seemed to have a protective effect on DSB (values < 0\%) in AG6000 and LL cells, which might be caused by the interstrand cross-links formed by this compound. In a previous study by Bergman et al (1996) it was postulated that $\mathrm{dFdC}$ incorporation into DNA could result in inhibition of the repair of Pt-DNA adducts, causing apparent stabilization of DNA. In the present study, this effect was indeed found in the A2780, ADDP and H322 cells, where a trend of less DSB formation than expected was found. However, in dFdC-resistant AG6000 cells more DSB than expected were formed, indicating that $\mathrm{dFdC}$ is necessary for the increase in DNA stabilization. An increase in DSB were also found in the murine cell line LL. Whether this phenomenon in the LL cell line is of much importance for the human situation remains to be seen. However, the above mechanisms apparently are not the only explanation for the synergistic interaction between both compounds in these cell lines.

$\mathrm{dFdC}$ hardly affected cellular Pt accumulation. The only exception was the ADDP cell line, in which $\mathrm{dFdC}$ clearly increased the Pt accumulation. In the cell CDDP binds to both DNA and protein, but to a much larger extent to protein (99\%); thus the increases in Pt accumulation in ADDP cells (overall 30\%) cannot be explained by the increase in Pt-DNA adduct formation. Therefore, an effect of $\mathrm{dFdC}$ on the binding of CDDP to intracellular proteins cannot be excluded.

The increase in Pt-DNA adduct formation could be the result of several effects of $\mathrm{dFdC}$ at the DNA level. Studies on the mechanism of interaction between DAC and CDDP revealed an increase of Pt-DNA binding on DAC substituted plasmid DNA (Abbruzzese and Frost, 1992), which was not hypomethylation dependent. Similarly, in our study there was a correlation between the incorporation of $\mathrm{dFdC}$ into DNA and the initial Pt-DNA adduct formation. The incorporation of $\mathrm{dFdC}$ into DNA could lead to structural changes favouring the binding of Pt to the guanine nucleotide opposite to the cytosine nucleotide and thus be of major importance in the synergistic interaction of both compounds.

Since the retention of DNA platination was not increased in the cell lines studied, $\mathrm{dFdC}$ did not seem to affect the overall DNA repair of Pt-DNA adducts in this setting. However, since the initial rapid repair of Pt-DNA adducts already starts a few hours after the adduct formation, this effect could in this study have been masked by the prolonged exposure period we used to be in accordance with the growth inhibition experiments.

Strikingly, the largest increase in initial Pt-DNA adduct formation by $\mathrm{dFdC}$ was found in the CDDP-resistant ADDP cell line, although this cell line did not show a significant increase in DNA stabilization after exposure to CDDP combined with $\mathrm{dFdC}$. $\mathrm{dFdC}$ might favour the formation of intra- instead of interstrand Pt crosslinks in this cell line. No increase in formation and retention of $\mathrm{Pt}-\mathrm{DNA}$ adducts was found in the $\mathrm{H} 322$ cell line. Since this cell line had the lowest level of $\mathrm{dFdC}$ incorporation into DNA, it might be postulated that a certain threshold $\mathrm{dFdC}$ incorporation is needed in a cell to induce the increased $\mathrm{Pt}-\mathrm{DNA}$ adduct formation.

This study shows that the combination of $\mathrm{dFdC}$ and CDDP can be synergistic in various cancer cell lines with a different histologic origin. The mechanism of this synergy is most likely an increase in the formation of Pt-DNA adducts, possibly related to the incorporation of $\mathrm{dFdC}$.

\section{ACKNOWLEDGEMENTS}

This study was supportal by grant IKA-VU 94-753 from the Dutch Cancer Society.

\section{REFERENCES}

Abbruzzese JL and Frost P (1992) Studies on the mechanism of the synergistic interaction between 2'-deoxy-5-azacytidine and cisplatin. Cancer Chem Pharmacol 30: 31-36

Abbruzzese JL, Grunawald R, Weeks EA, Gravel D, Adams T, Nowak B, Mineishi S, Tarassoff P, Satterlee W, Raber MN and Plunkett W (1991) A phase I clinical, plasma, and cellular pharmacology study of gemcitabine. J Clin Oncol 9: $491-498$

Abratt RP, Bezwoda WR, Goedhals L and Hacking DJ (1997) Weekly gemcitabine with monthly cisplatin: effective chemotherapy for advanced non-small cell lung cancer. J Clin Oncol 15: 744-749

Bergman AM, Ruiz van Haperen VWT, Veerman G, Kuiper CM and Peters GJ (1996) Interaction between cisplatin and gemcitabine in vitro. Clin Cancer Res 2: $521-530$

Birnboim HC and Jevcak JJ (1981) Fluorometric method for rapid detection of DNA strand breaks in human white blood cells produced by low doses of radiation. Cancer Res 41: 1889-1892

Braakhuis BJM, Ruiz van Haperen VWT, Welters MJP and Peters GJ (1995) Schedule-dependent therapeutic efficacy of the combination of gemcitabine and cisplatin in head and neck cancer xenografts. Eur J Cancer 31A: 1335-1340

Chiu CSM, Chan AK and Wright JA (1992) Inhibition of mammalian ribonucleotide reductase by cis-diamminedichloroplatinum(II). Biochem Cell Biol 70: $1332-1338$

Chou T-C and Hayball MP (1996) CalcuSyn, Windows Software for Dose Effect Analysis. Biosoft: Cambridge

Chou T-C and Talalay P (1983) Quantitative analysis of dose-effect relationship: the combined effects of multiple drugs on enzyme inhibitors. In Advances in Enzyme Regulation, G. Weber (ed), pp. 27-55. Pergamon Press: New York

Chou T-C, Motzer RJ, Tong Y and Bosl GJ (1994) Computerized quantitation of synergism and antagonism of taxol, topotecan, and cisplatin against human teratocarcinoma cell growth: a rational approach to clinical protocol design. J Natl Cancer Inst 86: 1517-1524

Crino L, Scagliotto G, Marangolo M, Figoli F, Clerici M, DeMarinis F, Salvati F, Cruciani G, Dagliotti L, Pucci F, Paccagnella A, Adamao V, Altavilla G, Incoronato P, Tripetti M, Mosconi AM, Santucci A, Sorbolini S, Oliva C and Tonato M (1997) Cisplatin-gemcitabine combination in advanced non-small cell lung cancer: a phase II study. J Clin Oncol 15: 297-303

Ellerhorst JA, Frost P, Abbruzzese JL, Newman RA and Chernajovsky Y (1993) 2 -deoxy-5-azacytidine increases binding of cisplatin to DNA by a mechanism independent of DNA hypomethylation. Br J Cancer 67: 209-215

Freeman KB, Anliker S, Hamilton M, Osborne D, Dhahir PH, Nelson R and Allerheiligen SRB (1995) Validated assays for the determination of gemcitabine in human plasma and urine using high-performance liquidchromatography with ultraviolet detection. J Chromatogr Biomed Appl 665 171-181

Heinemann V, Hertel LW, Grindey GB and Plunkett W (1988) Comparison of the cellular pharmacokinetics and toxicity of $2^{\prime}, 2^{\prime}$-difluorodeoxycytidine and 1- $\beta$ D-arabinofuranosylcytosine. Cancer Res 48: 4024-4031

Hertel LW, Kroin JS, Misner JW and Tustin JM (1988) Synthesis of 2'-deoxy-2', $2^{\prime}$ difluoro-D-ribose and $2^{\prime}$-deoxy-2', $2^{\prime}$-difluoro-D-ribofuranosyl nucleosides. J Org Chem 53: 2406-2409

Huang P, Chubb S, Hertel LW, Grindey GB and Plunkett W (1991) Action of 2',2'difluorodeoxycytidine on DNA synthesis. Cancer Res 51: 6110-6117

Krakowski I, Petit T, Kayitalire L, Weber B, Beaudouin M, Canon JL, Janssens J, Martin C and Belpomme D (1998) Gemcitabine (Gemzar) in combination with cisplatin (CP) in advanced ovarian cancers (AOC): a phase II study. Proc Am Soc Clin Oncol 17: 356a (abstract 1373)

Lu Y, Han J and Scanlon KJ (1988) Biochemical and molecular properties of cisplatin-resistant A2780 cells grown in folinic acid. J Biol Chem 263: 4891-4894

Monks A, Scudiero D, Skehan P, Shoemaker R, Paull K, Vistica D, Hose C, Langley J, Cronise P, Vaigro-Wolff A, Gray-Goodrich M, Campbell H, Mayo J and Boyd M (1991) Feasibility of a high-flux anticancer drug screen using a diverse panel of cultured human tumor cell lines. J Natl Cancer Inst 83: 761-766

Nogué M, Cirera L, Arcusa M, Tusquets I, Batiste-Alentorn E, Font A and Boto B (1998) Gemcitabine combined with cisplatin first line: a phase II study in 
patients with advanced epithelial ovarian cancer. Proc Am Soc Clin Oncol 17: 357a (abstract 1377)

Parker RJ, Gill I, Tarone R, Vionnet J, Grunberg S, Muggia F and Reed E (1991) Platinum DNA-damage in leucocyte DNA of patients receiving cisplatin and carboplatin chemotherapy, measured by atomic absorption spectrometry. Carcinogenesis 12: 1253-1258

Peters GJ, Laurensse E, Leyva A and Pinedo HM (1987) Purine nucleosides as cellspecific modulators of 5-fluorouracil metabolism and cytotoxicity. Eur J Cancer Clin Oncol 23: 1869-1881

Peters GJ, Wets M, Keepers YPAM, Oskam R, Van Ark-Otte J, Noordhuis P, Smid K and Pinedo HM (1993a) Transformation of mouse fibroblasts with the oncogenes H-ras or trk is associated with pronounced changes in drug sensitivity and metabolism. Int J Cancer 54: 450-455

Peters GJ, Schornagel JH and Milano GA (1993b) Clinical pharmacokinetics of antimetabolites. Cancer Surveys 17: 123-156

Ruiz van Haperen VWT, Veerman G, Vermorken JB and Peters GJ (1993) 2',2'Difluoro-deoxocytidine (Gemcitabine) incorporation into RNA and DNA of tumour cell lines. Biochem Pharmacol 46: 762-766

Ruiz van Haperen VWT, Veerman G, Eriksson S, Boven E, Stegmann APA, Hermsen M, Vermorken JB, Pinedo HM and Peters GJ (1994a) Development and characterization of a $2^{\prime}, 2^{\prime}$-difluorodeoxycytidine-resistant variant of the human ovarian cancer cell line A2780. Cancer Res 54: 4138-4143

Ruiz van Haperen VWT, Veerman G, Boven E, Noordhuis P, Vermorken JB and Peters GJ (1994b) Schedule-dependence of sensitivity to $2^{\prime}, 2^{\prime}$-difluorodeoxycytidine (Gemcitabine) in relation to accumulation and retention of its triphosphate in solid tumor cell lines and solid tumors. Biochem Pharmacol 48: 1327-1339

Ruiz van Haperen VWT, Veerman G, Vermorken JB, Pinedo HM and Peters GJ (1996) Regulation of deoxycytidine kinase from solid tumor cell lines by CTP and UTP. Biochem Pharmacol 51: 911-918
Scanlon KJ, Kashai-Sabet M, Tone T and Funato T (1991) Cisplatin resistance in human cancers. Pharmacol Ther 52: 385-406

Steward WP, Dunlop DJ, Dabouis G, Lacroix H and Talbot D (1996) Phase I/II study of gemcitabine and cisplatin in non-small cell lung cancer: preliminary results. Semin Oncol 5: 43-47

Sundquist WI and Lippard SJ (1990) The coordination chemistry of platinum anticancer drugs and related compounds with DNA. Coord Chem Rev 100 293-322

Terheggen PMAB, Emondt JY, Floot BGJ, Dijkman R, Schrier PI, Den Engelse L and Begg AC (1990) Correlation between cell killing by cis-

diamminedichloroplatinum(II) in six mammalian cell lines and binding of a cis-diamminedichloroplatinum(II)-DNA antiserum. Cancer Res 50: 3556-356

Van der Vijgh WJF (1991) Clinical pharmacology of carboplatin. Clin Pharmacokin 21: $242-261$

Van der Wilt CL, Smid K, Noordhuis P, Aherne GW and Peters GJ (1997) Biochemical mechanisms of interferon modulation of 5-fluorouracil activity in colon cancer cells. Eur J Cancer 33: 471-478

Van der Wilt CL, Visser GWM, Braakhuis BJM, Wedzinga R, Noordhuis P, Smid K and Peters GJ (1993) In vitro antitumour activity of cis- and trans-5-fluoro-5,6dihydro-6-alkoxy-uracils. Br J Cancer 68: 702-707

Van Moorsel CJA, Peters GJ and Pinedo HM (1997) Gemcitabine: future prospects of single-agent and combination studies. Oncologist 2: 127-134

Van Moorsel CJA, Pinedo HM, Veerman G, Vermorken JB, Postmus PE and Peters GJ (1999) Scheduling of gemcitabine and cisplatin in Lewis Lung tumour bearing mice. Eur J Cancer. In press

Vermorken JB, Van der Vijgh WJF, Klein I, Gall HE, Van Groeningen CJ and Pinedo HM (1984) Pharmacokinetics of free and total platinum species after rapid and prolonged infusions of cisplatin. Clin Pharmacol Ther 39: 136-144 